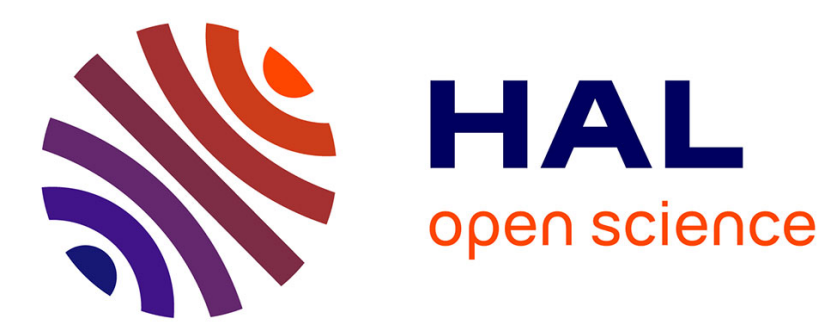

\title{
Knowledge Management in Design: A Perspective?
}

Mounib Mekhilef

\section{To cite this version:}

Mounib Mekhilef. Knowledge Management in Design: A Perspective?. Concurrent Engineering:

Research and Applications, 2007, 15 (1), pp.5-6. 10.1177/1063293X07077630 . hal-00571206

\section{HAL Id: hal-00571206 \\ https://hal.science/hal-00571206}

Submitted on 1 Mar 2011

HAL is a multi-disciplinary open access archive for the deposit and dissemination of scientific research documents, whether they are published or not. The documents may come from teaching and research institutions in France or abroad, or from public or private research centers.
L'archive ouverte pluridisciplinaire HAL, est destinée au dépôt et à la diffusion de documents scientifiques de niveau recherche, publiés ou non, émanant des établissements d'enseignement et de recherche français ou étrangers, des laboratoires publics ou privés. 


\title{
I - S concurrent engineering: Research and Applications
}

\section{Knowledge Management in Design: A Perspective?}

\author{
Mounib Mekhilef," Guest Editor \\ Department of Industrial Engineering, Ecole Centrale Paris
}

In recent years Knowledge Management (KM) is becoming a necessity for many companies interested in meeting the challenges of ongoing organizational changes and growing global competitiveness. In scientific literature KM appears more or less a unified but somewhat generative 'field of research'. A detailed analysis of the scientific works in KM, however, reveals that the management of knowledge and competence has become a preoccupation in its own right. A number of actors (university, consultant, industrial, etc.) now constitute a large community of KM experts with a profusion of publications, various network groups, and specialized training offers. Currently, there exist several points of view and interpretations to the notion of knowledge and competence management.

From the research perspective, the developments in $\mathrm{KM}$ are spreading in many fields, including: Decision Science, Social Sciences, Engineering, Computer Science, Medicine, Business, and Economy. The processes related to the knowledge life cycle are currently being evaluated from several angles including well established pragmatic point of views. There are actually strong relations between the pragmatic points of view and the arguments of more ontological nature. Papers addressing both these points of view are covered in the current issue.

For example, when knowledge is envisaged as 'information organized for the resolution of problems' the idea of knowledge therein implicitly represents entities that are already formalized. This is quite

*E-mail: mounib.mekhilef@ecp.fr different compared to a resolution process (such as statements susceptible to formal treatments) or, a minima, in organized categories without having formal processes or a priori treatment. If an author deals with KM from a specific field or discipline (say information sciences, or engineering), the true meaning and the practical echo of the underlying concepts will not be of the same nature. In other words, the notion of knowledge must be considered both from a pragmatic point of view (what it conveys in a certain context or action) and in reference to an ontological context (such as a universe). Consequently, the epistemological level would be an important consideration.

In addition, two other contextualization of the pragmatic approach should also be considered in dealing with KM:

1. The first knowledge contextualization is connected to a particular context in a company. Even though one can envisage generic approaches to $\mathrm{KM}$, each company is accustomed to using knowledge in a particular way.

2. The second contextualization is connected to the strategic context in which a KM system is envisaged and is deployed. Indeed, as one aims at a strategy of innovation or at a strategy in supporting a company decision, the conceptualization approach ought to be much more encompassing. In this context, there could be five different types of implementation strategy of a KM system each requiring a different methodology:

- Strategy for business;

- Strategy for intellectual resources management;

- Strategy for the personal knowledge responsibility; 
- Strategy for knowledge creation;

- Strategy for knowledge transfer.

In this special issue on Knowledge Management in Design, we have captured such seven points of view in an attempt to provide a broader picture of the KM varieties. From the epistemological perspective, the issues in Design Management are no longer related to the nature of knowledge, nor its functionality, but the way we capture both explicit and implicit knowledge into a suitable resource or wizard to ensure better product designs.

Raymond Houe and Bernard Grabot present in their paper for this issue a methodology first to capture the embedded knowledge in some standards and norms and then describe how to turn them into textual statements for managing design constraints. In another paper by Chun-Bao Chen and Li-Ya Wang, the authors provide a promising method of knowledge capture through classification and clustering of past experience and accumulated knowledge. Another issue in KM is the knowledge sharing in collaborative works. Karen Ostergaard and Joshua Summers provide in their paper an interesting way to handle resistance to knowledge sharing in design process using an analogy with electrical circuits.

In accordance with the field of Computer Science, $\mathrm{KM}$ is mainly based on developments that started as early as the works from Turing. The management of knowledge is considered as a management of information, and consequently, all the techniques developed in the field of Computer Science can be used in KM. As an illustration of this approach, Movahed-khah and his colleagues from the Technical University of Monbeliard present a multi-agent approach to support the collaboration among multi-disciplinary teams. In dealing with integrated design approaches such as Concurrent Engineering, we often face a need to integrate all the constraints set from the early stage to the end of the product life cycle. This involves various disciplines, many objectives and processes. Jie $\mathrm{Hu}$ and his colleagues from the Institute of Knowledge Based Engineering at the University of Shanghai provide a coherent methodology in their paper that can handle such knowledge varieties.

At an early stage of design, capturing the knowledge related to the user preference is one of the important concerns in KM. This topic has been addressed in literatures from various perspectives, such as Decisionbased Design, Design Optimization, and Design Preferences. Yoon-Eui Nahm and his colleagues from the Hanbat National University in Korea, propose a resolution of this topic through the consideration of designer's preferences. In this case, the knowledge that authors consider is the one handled by the designers rather than the one embedded in the processes. From an educational perspective, this special issue also provides some useful insights around Design Education. Vassilis Agouridas and Phil Race from the University of Leeds, suggest a systematic reflection practice as a way to enhance Knowledge Management in design.

In this issue of the journal, one can find evidence that support the arguments that in order to manage Knowledge in Design generatively, one needs to embed them into a KM process. To this effect, research accounts for managing knowledge at all levels: strategic, tactical, and operational. Some also consider the management of knowledge from the product, process, and organization perspectives. The papers presented in this special issue, however, only represent a small crosssection of research points of view. In order to take some of them to greater heights undoubtedly more research is needed and the editors hope that this special issue will provide a step for doing further research and development. The Guest Editor would like to thank Dr. Brian Prasad for the opportunity to output this special issue and help in making it happen.

Respectively submitted Mounib Mekhilef 